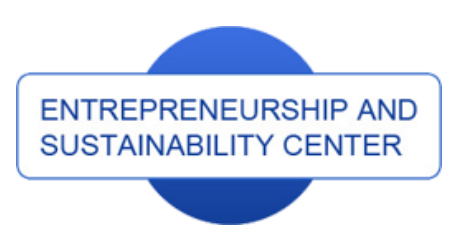

Publisher

http://jssidoi.org/esc/home

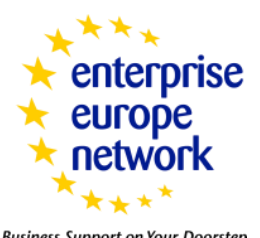

Business Support on Your Doorstep

\section{Scopus}

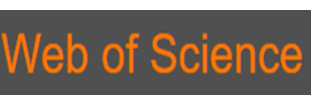

1 Clarivate

Analytics

\title{
DESTRUCTIVE MOTIVATION OF PERSONNEL: A CASE STUDY OF RUSSIAN COMMERCIAL COMPANIES
}

\author{
Alexander Borisov', Diana Narozhnaia², Elena Tarando ${ }^{3}$, Alexey Vorontsov ${ }^{4}$, Nikolay Pruel $^{5}$, Olga \\ Nikiforova ${ }^{6}$ \\ 1, 3, 5, 6 Saint-Petersburg State University, ${ }^{2}$ Moscow State University by the name of M.V. Lomonosov, ${ }^{4}$ Herzen State \\ Pedagogical University of Russia \\ E-mails: ${ }^{3}$ elena.tarando@yandex.ru
}

Received 10 March 2018; accepted 20 August 2018; published 30 September 2018

\begin{abstract}
The article analyzes the results of an empirical study of the causes of destructive motivation of personnel in Russian commercial organizations. The study was conducted by questioning two hundred employees of commercial organizations in Moscow. The purpose of the research is to reveal the opinion of employees on the causes of destructive motivation of personnel and measures for their elimination. The empirical study revealed the influence of organizational factors on the existence of destructive personnel motivation in organizations, such as: labor organization; remuneration system, benefits and career management; control over the activities of employees; group communications and organizational culture. The study revealed the impact of personal characteristics of employees on destructive motivation. In the course of the survey, the degree of influence of various groups of reasons on the demotivation of employees in the studied commercial organizations was revealed, as well as on the micro-political motivation of employees. In the course of the questionnaire, assessments of the main forms of destructive behavior were obtained, which allowed for developing more detailed recommendations for limiting this negative phenomenon. The practical significance of the research is the results of an analysis of various factors of the internal environment of the organization and the personal characteristics of employees that are significant for the formation of destructive motivation of employees of Russian companies in a transitional economy.
\end{abstract}

Keywords: motivation; demotivation; destructive motivation; deviation; anomie; micro-political motivation; motivational policy; destructive motivation model

Reference Borisov, A.; Narozhnaia, D.; Tarando, E.; Vorontsov, A.; Pruel, N.; Nikiforova, O. 2018. Destructive motivation of personnel: a case study of Russian commercial companies, Entrepreneurship and Sustainability Issues 6(1): $253-267$. http://doi.org/10.9770/jesi.2018.6.1(16)

JEL Classifications: M12, M54, M59

Additional disciplines: sociology; psychology 


\section{Introduction}

Historical experience convincingly demonstrates that the motivation of employees, including managers, their desire for conscientious and initiative work is one of the key factors for the success and failure of any business organization. Until recently, the main attention of scientists and practitioners-leaders was paid to constructive motivation, searching for ways to increase it, with no proper attention to motivating the destructive, hindering the achievement of the organization's goals. And, meanwhile, this type of motivation causes immense harm to the organization generates a number of negative phenomena, such as protectionism, nepotism, internal dismissal of an employee, sabotage and even economic crimes: corruption, theft, abuse of power, etc. The destructive motivation of personnel leads to a decrease in the rate of production, profit, quality of products or services, conflicts in the team, strained relations between employees and employers, and other negative consequences. All these threaten the stability of the organization, and often its very existence. Managers of organizations are aware of the danger of this negative phenomenon, but they note that the management of the destructive motivation of the personnel is one of the most important and difficult tasks for them.

Indeed, the enormous negative impact of destructive motivation on the activities of organizations, the weak scientific and theoretical elaboration of questions about the causes and consequences of the reproduction of this socio-managerial phenomenon, and the lack of systematic recommendations in the scientific literature to limit destructive motivation determine the relevance of the topic of this study.

The purpose of this article is to identify and systematize the main causes of destructive motivation of personnel in commercial organizations, as well as the development of a set of recommendations for limiting this negative phenomenon. This goal can be achieved by solving the following tasks: identifying key causes of destructive behavior of personnel; investigating the degree of influence of the characteristics of the internal environment of the organization on the existence of destructive organization of personnel; identifying the main forms of destructive behavior of personnel in commercial organizations; developing a set of recommendations on eliminating or limiting the causes of destructive motivation of personnel in commercial organizations of modern Russia.

The study contained the following hypothesis: the main reasons for the destructive motivation of the personnel are such characteristics of the internal environment of the organization as unfair and too low remuneration, as well as imperfection of the system of control over the activities of employees.

\section{Literature review}

In the scientific literature, the destructive motivation of employees is investigated as a type of labor motivation and contrasted with constructive motivation, the realization of which allows the organization to achieve its goals. In the world scientific literature, the study of destructive motivation and destructive organizational behavior as its manifestation was made primarily with respect to the identification of its various species and the construction based on this classification. Thus, such types of destructive organizational behavior as aggressive behavior towards colleagues in the work, poor performance of their duties, sabotage, including deterioration of the property of the organization, theft, absenteeism, expressed in delays, deliberate increase in breaks, etc., were singled out (Spector et al., 2006). In addition, there are developments in which destructive behavior is classified according to the level at which its consequences are felt. Thereby two main such levels are distinguished: interpersonal, when destructive behavior harms concrete employees working in the organization (aggression, insults, rumors, etc.), and organizational, when the damage is done to the organization (absenteeism, sabotage, theft, etc.) (Bashir et al., 2012). 
Currently, researchers of destructive motivation came to the conclusion that this phenomenon can be generated by measures for the formation of constructive motivation. If earlier it was believed that such measures either bring the intended result, or have no effect, now scientists have come to the conclusion that the result of such measures can be negative, forming a destructive motivation. Thus, R. Faullant and G. Dolfus (2017) write that managers "have to be aware that "Top Innovators" lists are a double-edged sword. On the one hand, they are a perfect motivator for members to be constantly active; on the other hand, these lists create fierce competition among contestants, inducing some of them to misuse interaction channels or even to sabotage other members" (Faullant, Dolfus, 2017).

In studies of destructive motivation, the internal environment of the organization is indicated as its main source at the present time. Therefore, the study of this phenomenon is conducted in the direction of identifying elements of this environment and their influence on the formation of destructive motivation and destructive behavior. "Toxic" management practices are seen as one of such key elements. Authors investigating this factor, suggest building strong ties between employees as an antidote: "By creating an environment that enhances and maintains adaptive and safe interactions among employees, organizations can reduce employees' overdependence on their supervisor for the need to feel valued and help buffer the negative consequences associated with abusive supervision" (Vogel, Mitchell, 2017: 2246). Similar recommendations are given by other authors investigating this phenomenon (Indradevi, 2016; Vogel et al., 2016; Hommelhaft, 2017; Pink, 2013). The opportunistic behavior of employees is studied both consequentially and in line with the determining influence of the internal environment of the organization on the formation of destructive motivation (Auriol, Brilon, 2018; Ma, 2016; Neuberger, 2015; Dhar, 2012; Brown et al., 2009; Blickle et al., 2006).

The Russian scientific literature sees the problematic of destructive motivation as relatively new. Its analysis can be seen in several planes. First of all, the factors that form this kind of labor motivation among employees are revealed. In particular, such factors as excessive regulation of labor and organizational behavior, personal problems (family relationships, domestic difficulties, etc.), personal qualities negative for the labor process (laziness, lack of internal discipline, irresponsibility, conflictness ), etc. (Snisarenko, 2017). It is noted that the destructive motivation is investigated from the point of view of the effectiveness of the organization's objectives as damaging this effectiveness (Duduyeva et al., 2016; Dudina, 2017; Rubtcova, Mart'yanova, 2016; Kharitonova, 2013). Simultaneously, a number of researchers analyze the influence of individual factors of destructive motivation on the effectiveness of work collectives (Brazevich, Misyukevich, 2016, Pugachev, 2014, Khaliullina, 2010).

There is a layer of scientific literature in which studies of destructive motivation are carried out in various professional groups, such as school teachers (Fedosova, 2016, Rakitskaya, 2015, Popova, 2014), civil servants (Dan'kova, 2017; Vasilieva, Rubtcova, 2017; Rubtcova, Vasilieva, 2015), employees of the Ministry of Internal Affairs (Zlokazov, 2014; Osintseva, 2013). This attention to these professional groups responds to the social importance of their professional functions.

In addition, it is noted that in connection with the transition of Russia in the 1990s to a market economy, there is an intergenerational difference in value systems, when the value system of the older generation, brought up under the dominance of Soviet values, differs significantly from the value system of the younger generation. Moreover, the younger generation is also not a homogeneous social group: the introduction of digital technologies into the social life forms a system of values corresponding to the digital society in the generation that grew up in these conditions (Ivanov, 2016). Differences in value systems determine differences in motivation of work among different generations of employees and, as a result, differences in conditions, causes and structure of destructive motivation of labor activity (Rybianets, 2016; Skvortsov, 1999). 


\section{The International Journal}

ENTREPRENEURSHIP AND SUSTAINABILITY ISSUES

ISSN 2345-0282 (online) http://jssidoi.org/jesi/

2018 Volume 6 Number 1 (September)

http://doi.org/10.9770/jesi.2018.6.(16)

As a result of the analysis of destructive motivation, a number of authors suggest models of such motivation associated with models of self-development of an employee (Snisarenko, 2017) and models of labor potential of an employee and organization (Simonenko, 2011; Mikheeva, 2005). It is noted that destructive motivation is a phenomenon embedded in these models, which can accompany the labor process in any category of employees.

There is another aspect of the study of destructive motivation in Russian literature: an analysis of its forms (Zmanovskaya, 2004; Spivak, 2006; Donskikh, Korolenko, 1990; Sackett et al., 2006; Boykov, 2004; Kudryavtsev, 2007; Luneev, 2005; Bogdanova , 2010) and types such as demotivation and micro-political demotivation (Belkin, 2009; Andreeva, Yurtaikin, 2002; Ivanova, 2013; Kuznetsova, 2012; Tkachenko, 2011; Florovsky, 2011; Sprenger, 2007).

An important component of studies of destructive motivation is the search for restrictors of this phenomenon of working life (Veselov, 2000). At the same time, focusing on the analysis of conditions, causes, social nature, the structure of this phenomenon, the authors, as a rule, only state the existence of destructive motivation and the necessity of its restriction. Some manuscripts give recommendations on overcoming a number of its negative consequences. At the same time, social technologies for limiting destructive motivation are not sufficiently analyzed in the scientific literature, which makes it urgent to study social practices of limiting destructive motivation in Russian organizations and analyzing relevant technologies.

\section{The method for studying the destructive motivation of the personnel}

The purpose was to find out the causes of the destructive motivation of staff at the level of the internal environment of the organization and at the level of the employee's personality. To reach this purpose, a sociological survey was conducted in the form of a questionnaire survey of employees of such commercial companies as "Novard", "Bovstr", and "Protection" in Moscow. These companies represent different levels of business: small $(22 \%)$; medium $(50 \%)$, and large (28\%). They specialize in software development, educational services, consulting, construction, and repair of banks and offices, as well as real estate sales. The total sample size was $\mathrm{N}=200$ respondents. The sampling type is a non-random sample using the snowball sampling method, which assumed that subsequent respondents were selected after reference to the initially selected respondents. The study was conducted on a structured questionnaire, which was sent to respondents by e-mail for completion. The method of questioning, developed by the authors, was used to make up the theoretical model of destructive motivation of personnel. Accordingly, the questions of the questionnaire were put to respondents for each block of identified factors (subsystems) that determine the destructive motivation: the organization of labor; rewards and benefits; control over the activities of employees; group communications and organizational culture; personal characteristics of the employee. The respondents were to assess the extent to which they affect the existence of destructive motivation in the organization. The questionnaire included 11 questions concerning the essence of the phenomenon under study, as well as 4 questions of the passport. The total number of questions was 22 .

The formulation of the questions was simplified as much as possible in order to ensure their adequate understanding by respondents who are not familiar with the main categories of the concept of destructive motivation, although they regularly encounter such motivation in their practical activities. The obtained data allowed for analyzing the most complex aspects of the problem, to justify the conclusions and make practical recommendations. The object of the study is the destructive motivation of the personnel of commercial organizations in Moscow. The subject of the research - is the interaction between the characteristics of the internal environment of the organization and the personal characteristics of employees when determining the destructive motivation of personnel. The main goal of the research is to reveal the opinion of employees on the degree of influence of the theoretically determined groups of causes on the existence of destructive motivation of personnel. The following tasks were set for this goal as defining: 
- Attitude of respondents to destructive organizational behavior in general, and to its various types (theft, fraud, absenteeism, etc.), in particular;

- The most dangerous for the organization from the point of view of the respondents are the types of destructive organizational behavior;

- The determinism degree of destructive motivation by the characteristics of the internal environment of the organization, contained in the subsystems of the organization of labor; remuneration, benefits and career management; control over the activities of employees, personnel assessment and punishment of violators of organizational order; organizational culture; group communications;

- Degree of determinism of destructive motivation by personal characteristics of employees;

- Degree of influence of the causes of the destructive motivation of the internal environment of the organization and the personal causes of destructive motivation for the implementation of various forms of destructive organizational behavior. The study contained the following hypothesis: The main reasons for the destructive motivation of the personnel are the following characteristics of the internal environment of the organization: unjust remuneration in the opinion of employees, too low remuneration; imperfection of the control system over the activity of employees.

The total sample size was 200 respondents. The sample is random. An empirical study of the problem of destructive motivation of personnel in commercial organizations is associated with a number of difficulties that significantly complicated its implementation. Certain restrictions on the conduct of the study imposed a sensitivity of the topic; the respondents answered questions with caution, because they were afraid to appear in an unfavorable light. Also, in spite of the fact that some aspects of destructive motivation are rather widely discussed within the framework of management theory, on the whole, the very notion itself does not have a wide distribution in the mass consciousness, and the respondents understood it with a significant degree of subjectivity. In addition, until now there is no well-developed sociological toolkit necessary for data collection and subsequent analysis of the destructive motivation of personnel. Despite the difficulties associated with the study of destructiveness in specific organizations, the results obtained are of some interest for identifying the reasons for the reproduction of destructive motivation, their configuration, and the degree of expression in modern Russian companies. They also provide an opportunity to consider the problem of destructive motivation of personnel from the organizational and managerial point of view, which makes it possible to develop comprehensive recommendations to limit this negative phenomenon.

\section{Results}

When carrying out the questionnaire, respondents were asked to assess the degree of influence of the grouped characteristics of the internal environment of the organization and the personal qualities of the employee on the existence in the organization of destructive motivation of the personnel. The study was also focused at analyzing the subordination of the causes of the destructive motivation of meso- and micro-level personnel.

At the first stage, the respondents were consistently asked questions about the significance of all the models, modeled theoretically and reflected in the models developed by the author, the causes of destructive motivation, which are characteristics of the internal environment of the organization.

Table 1 shows the results of determining the degree of influence of the characteristics of the labor organization subsystem on the existence of destructive motivation in the organization (Table 1). 
Table 1. Influence of the characteristics of the subsystem of labor organization on the destructive motivation of personnel

\begin{tabular}{|c|c|c|c|}
\hline Destructive motivation factors & \multicolumn{2}{|c|}{ Answers (\%) } \\
\cline { 2 - 4 } & Affects a lot & Affects partially & Does not affect \\
\hline $\begin{array}{c}\text { Unclearly formulated and (or) unknown to } \\
\text { employees goals, tasks and requirements of the } \\
\text { organization (employees do not exactly know what } \\
\text { results they need to achieve, therefore they act at } \\
\text { own discretion) }\end{array}$ & 52.5 & 37.5 & 10.0 \\
\hline $\begin{array}{c}\text { Lack of feedback when performing tasks (the } \\
\text { supervisor does not give comments, assessments, } \\
\text { advice when doing the work) }\end{array}$ & 37.5 & 52.5 & 10.0 \\
\hline $\begin{array}{c}\text { Unattractive working conditions (noise, insufficient } \\
\text { illumination, lack of air conditioning, etc.) }\end{array}$ & 37.5 & 57.5 & \\
\hline $\begin{array}{c}\text { The content and characteristics of labor do not } \\
\text { correspond to the employee's expectations (work is } \\
\text { too monotonous, tedious, uninteresting, tasks do not } \\
\text { have significance, or, on the contrary, work requires } \\
\text { excessive responsibility, etc.) }\end{array}$ & 42.5 & 27.5 & 3.0 \\
\hline $\begin{array}{c}\text { Fuzzy division of functions, responsibilities and } \\
\text { powers between employees, allowing to act at own } \\
\text { discretion }\end{array}$ & 40.0 & & 30.0 \\
\hline
\end{tabular}

$52.5 \%$ of respondents think that the goals, tasks and requirements of the organization are vaguely formulated and (or) unknown to employees, that is, the situation when employees do not exactly know what results they need to achieve, which most strongly affects the existence of destructive motivation.

The result is explained by the presence of "gray zones" in a situation when the goals, tasks and requirements of the organization do not fulfill their normative function, which provokes the spread of micro-policy. Also, this situation can turn into a state of frustration for employees, which grows into demotivation, resulting in absenteeism.

In addition to assessing the significance of the causes of the destructive motivation of the personnel, the respondents had the opportunity to complete the characteristics that they believe also affect the existence of destructive motivation of the personnel within each of the allocated subsystems. The availability of such independent answers as "the absence of a sense of belonging to something important, significant, creative component" became indicative; "lack of verification of psychological compliance with the workplace when hiring". These answers show a high level of consciousness of the interviewed employees who perceive work activity as a need of the individual, as well as an interest in providing objective data for the ongoing research.

In the subsystem of remuneration, benefits and career management, the greatest impact on the existence of destructive personnel motivation, according to respondents, is the injustice of remuneration - 87.5. In the second place was too low remuneration of labor, its influence was noted by $77.5 \%$ of respondents (Table 2 ). 
Table 2. Influence of characteristics of a subsystem of compensations, privileges and management of career on destructive motivation of the personnel

\begin{tabular}{|c|c|c|c|c|}
\hline \multirow{2}{*}{ Destructive motivation factors } & \multicolumn{3}{|c|}{ Answers (\%) } \\
\cline { 2 - 5 } & Affects a lot & $\begin{array}{c}\text { Affects } \\
\text { partially }\end{array}$ & Does not affect & Difficult to answer \\
\hline Lack of career perspectives & 35.0 & 42.5 & 20.0 & 2.5 \\
\hline $\begin{array}{c}\text { Lack of possibilities for training and } \\
\text { advanced training }\end{array}$ & 20.0 & 45.0 & 32.5 & 2.5 \\
\hline $\begin{array}{c}\text { Lack of social package or its mismatch with } \\
\text { the expectations of an employee }\end{array}$ & 10.0 & 65.0 & 22.5 & 2.5 \\
\hline Injustice of remuneration for the labor & 87.5 & 12.5 & 0 & 0 \\
\hline Too low remuneration & 77.5 & 22.5 & 0 & 0 \\
\hline
\end{tabular}

As a result of the survey, a correlation was found between the age of respondents and the degree of their influence that lack of career prospects on organizational behavior. A younger group of respondents identified this characteristic as the cause of destructive motivation more often than a group of more mature respondents.

Among the characteristics of the subsystem for monitoring the activities of employees, assessing personnel and punishing violators of the organizational order, the most significant, in the opinion of the respondents, is the situation in which control over the activities of employees is weak or absent. $64.1 \%$ of respondents noted the influence of this reason on destructive motivation of personnel.

The second place in importance among the characteristics of this subsystem went to the situation in which the facts of destructive organizational behavior remain unpunished, or the punishment turns out to be excessively mild. Its impact was noted by $51.3 \%$ of respondents (Table 3 ).

Table 3. Influence of the characteristics of the subsystem of control over the activities of employees in assessing personnel and punishing violators of organizational order for the destructive motivation of personnel

\begin{tabular}{|c|c|c|c|c|}
\hline \multirow[t]{2}{*}{ Destructive motivation factors } & \multicolumn{4}{|c|}{ Answers (\%) } \\
\hline & Affects a lot & $\begin{array}{l}\text { Affects } \\
\text { partially }\end{array}$ & Does not affect & $\begin{array}{l}\text { Difficult to } \\
\text { answer }\end{array}$ \\
\hline $\begin{array}{c}\text { Absence or excessive softness of } \\
\text { punishment for destructive behavior }\end{array}$ & 51.3 & 43.6 & 2.6 & 2.6 \\
\hline $\begin{array}{c}\text { Control by fellow employees is absent or } \\
\text { extremely weak }\end{array}$ & 10.3 & 30.8 & 51.3 & 7.7 \\
\hline $\begin{array}{l}\text { The evaluation of employees, their work, } \\
\text { competencies and organizational behavior } \\
\text { is inadequate and is perceived as unfair }\end{array}$ & 25.6 & 46.2 & 10.3 & 17.9 \\
\hline $\begin{array}{l}\text { Control by management for the activity of } \\
\text { the employees is weak or absent }\end{array}$ & 64.1 & 30.8 & 5.1 & 0 \\
\hline
\end{tabular}

Thus, when developing recommendations for limiting destructive motivation, it is also necessary to give special attention to building an optimal system for controlling the activities of employees.

The need to develop an effective monitoring system is also confirmed by the results obtained when answering the question of how the situation in which employees are given ample opportunities to act at their discretion is affected by the destructive motivation, their duties are not clearly regulated by rules and regulations, and their control is weakened or absent. $68 \%$ of respondents believe that with insufficient level of external control and regulation of the organizational process, destructive motivation will be widespread. Employees will work worse and more often pursue only their personal interests to the detriment of the interests of the company. At the same time, only $32 \%$ of respondents noted that a decrease in the degree of external control will allow employees to 
The International Journal

ENTREPRENEURSHIP AND SUSTAINABILITY ISSUES

ISSN 2345-0282 (online) http://jssidoi.org/jesi/ 2018 Volume 6 Number 1 (September) http://doi.org/10.9770/jesi.2018.6.(16)

more effectively open their potential. The authors believe that the data obtained indicate a low level of internal motivation of this part of the respondents, as well as an insufficient degree of their identification with the organization and involvement in the work process. Theoretical analysis of the problem of destructive motivation has shown that the characteristics of subsystems of group communications and organizational culture exert a significant influence on the existence of destructive motivation. The respondents' opinion on the degree of influence of the characteristics of these subsystems on the existence of destructive motivation of personnel in the organization is reflected in Table 4.

Table 4. Influence of characteristics of subsystems of group communications and organizational culture on destructive motivation of the personnel

\begin{tabular}{|c|c|c|c|c|}
\hline Destructive motivation factors & \multicolumn{3}{|c|}{ Answers (\%) } \\
\cline { 2 - 5 } & Affects a lot & $\begin{array}{c}\text { Affects } \\
\text { partially }\end{array}$ & $\begin{array}{c}\text { Does not } \\
\text { affect }\end{array}$ & $\begin{array}{c}\text { Difficult to } \\
\text { answer }\end{array}$ \\
\hline $\begin{array}{c}\text { Organizational culture in which destructive } \\
\text { organizational behavior is acceptable is not } \\
\text { condemned }\end{array}$ & 33.3 & 25.6 & 17.9 & 5.1 \\
\hline $\begin{array}{c}\text { Unhealthy psychological climate in the team } \\
\text { (regular conflicts, acute competition, lack of } \\
\text { mutual assistance and support among employees) }\end{array}$ & 53.8 & 35.9 & 10.3 & 0 \\
\hline $\begin{array}{c}\text { Official (professional and managerial) } \\
\text { incompetence of the manager }\end{array}$ & 35.9 & 38.5 & 15.4 & 10.3 \\
\hline $\begin{array}{c}\text { Immoral, unjust behavior of the manager towards } \\
\text { subordinates }\end{array}$ & 51.3 & 33.3 & 15.4 & \\
\hline $\begin{array}{c}\text { The role of an employee in an informal group } \\
\text { (leader, performer, adviser, expert, etc.) and the } \\
\text { functions corresponding to it do not meet his } \\
\text { inclinations and expectations }\end{array}$ & 17.9 & 41.0 & 20.5 & 20.5 \\
\hline
\end{tabular}

Among the causes of destructive motivation contained in these subsystems, the most significant, in the opinion of respondents, has such characteristics as unhealthy psychological climate in the team (53.8\%). It is significant that the second most popular among the reasons for this subgroup was the factor of immoral, unjust behavior of the manager towards subordinates $(51.3 \%)$. The authors believe that the high degree of significance of this cause of destructive motivation is associated with long traditions of authoritarian governance in the country, low moral qualities of managers, and lack of managerial knowledge and competencies.

There are many people among the managers of Russian companies, who do not have professional knowledge of how to manage subordinates and are not accustomed to reckon with them, respect their rights. This situation, in turn, becomes a significant reason for the development of destructive motivation of personnel in organizations.

Noteworthy was one of the independent answers about the causes of the destructive motivation of this subsystem of the organization, which was formulated as "non-observance of gender balance in the team". Undoubtedly, the specific nature of the sphere of activity of the organization, as well as the specific division, determines the gender composition existing in them. Thus, if the organization is engaged in IT, then it is mostly men, who work there, but, for example, women are mainly employed in the HR department. However, as shown by psychological research, for the most productive activities, it is necessary to maintain a gender balance, since its impact on the consciousness and behavior of employees is sufficiently significant.

A comprehensive analysis of destructive motivation and development of practical recommendations for limiting it, in addition to investigating the causes of destructive motivation, which are characteristics of various subsystems of the internal environment of the organization, also requires considering the causes of destructive motivation associated with the personal characteristics of employees. In accordance with this, respondents were 
The International Journal

ENTREPRENEURSHIP AND SUSTAINABILITY ISSUES

ISSN 2345-0282 (online) http://jssidoi.org/jesi/

2018 Volume 6 Number 1 (September)

http://doi.org/10.9770/jesi.2018.6.(16)

asked about the degree of influence of various personal characteristics of employees on the destructive motivation of the personnel. Table 5 shows how the answers to this question were distributed.

Table 5. Influence of personal characteristics of employees on destructive motivation

\begin{tabular}{|c|c|c|c|c|}
\hline Destructive motivation factors & \multicolumn{3}{|c|}{ Answers (\%) } \\
\cline { 2 - 5 } & Affects a lot & $\begin{array}{c}\text { Affects } \\
\text { partially }\end{array}$ & $\begin{array}{c}\text { Does not } \\
\text { affect }\end{array}$ & $\begin{array}{c}\text { Difficult to } \\
\text { answer }\end{array}$ \\
\hline $\begin{array}{c}\text { Properties that are a manifestation of certain } \\
\text { deviations in personal development, psychological } \\
\text { complexes, "strangenesses", etc. }\end{array}$ & 28.2 & 30.8 & 17.9 & 23.1 \\
\hline $\begin{array}{c}\text { Insubstantiality, manifested in a tendency to cause } \\
\text { disposition and self-confidence in flattery, feigned } \\
\text { courtesy }\end{array}$ & 10.3 & 51.3 & 25.6 & 12.8 \\
\hline $\begin{array}{c}\text { Sufficiently developed intellect and self-awareness, } \\
\text { personal autonomy, independent judgments, critical } \\
\text { thinking }\end{array}$ & 15.4 & 20.5 & 51.3 & 12.8 \\
\hline $\begin{array}{c}\text { Increased predisposition to risk and adventurism } \\
\text { Low moral standards, lack of sustainable ethical } \\
\text { values, moral insensitivity }\end{array}$ & 38.5 & 33.3 & 7.7 & 20.5 \\
\hline $\begin{array}{c}\text { Predisposition to destructive behavior based on a } \\
\text { successful past experience }\end{array}$ & 43.6 & 35.9 & 7.7 & 12.8 \\
\hline Individualism and selfishness & 20.5 & 53.8 & 20.5 & 5 \\
\hline $\begin{array}{c}\text { Lack of spirituality, orientation only on material } \\
\text { prosperity }\end{array}$ & 12.8 & 53.8 & 28.2 & 5.1 \\
\hline
\end{tabular}

According to respondents, such personal qualities of the employee as predisposition to destructive behavior on the basis of successful past experience and low moral standards, the lack of sustainable ethical values, and lack of principle have the greatest influence on the existence of destructive motivation. These responses got $43.6 \%$ and $38.5 \%$ respectively.

Independent answers of the respondents as per this group of factors are also interesting. Thus, they called "laziness and unwillingness to work", "active destructive inner beginning" - inducing their colleagues to destructive behavior such as "let's skip a class altogether" - as the personal qualities of employees who determine destructive organizational behavior.

An important, in our opinion, addition to the highlighted theoretically personal characteristics is the initiative response of one of the respondents, according to whom the cause of destructive motivation can be the situation of "the employee's capacity limit (inability of an employee to do work above a certain level)". The following characteristics correlates with the previous one: "the employee is employed not in accordance with the diploma and received specialty". That is, the shortage of the employee's abilities is aggravated by managerial mistakes, for example, by assigning tasks that require the employee to have the competence they do not have, or the superpower for which they are not capable. In the end, this leads to destructive motivation.

\section{Discussion}

The study by E.N. Mikheeva (2005) is the one that mostly correlates with the tasks of this manuscript among the empirical studies devoted to destructiveness in organizational behavior published in the recent years. She conducted an analysis of the labor behavior of the employees of Lukoil-Volgogradneftepererabotka and SiburVolzhsky in Volgograd, and one of the areas of analysis was the identification of factors that determine destructive behavior at enterprises. 
The International Journal

ENTREPRENEURSHIP AND SUSTAINABILITY ISSUES

ISSN 2345-0282 (online) http://jssidoi.org/jesi/

2018 Volume 6 Number 1 (September)

http://doi.org/10.9770/jesi.2018.6.(16)

According to the results of E.N. Mikheeva (2005), the key reasons for the implementation of destructive behavior are the following: insufficient accounting of labor results $(26.1 \%$ and $39.6 \%)$ - as of now and further brackets contain the percentages of employees of enterprise- 1 and enterprise-2, who noted this factor as determinative destructive behavior; poor condition of the equipment $(37.2 \%$ and $78.0 \%)$, unsatisfactory sanitary conditions of work (22.9\% and $47.4 \%$ ), a system of moral and material incentives that does not meet the needs of employees (42.7\% and $73.4 \%)$, lack of opportunities for professional growth (17.5\% and $47.1 \%)$; unsatisfactory relations with the head $(44.0 \%$ and $43.0 \%)$, and low remuneration (45.6\% and $88.5 \%)$.

As a result of her research, E.N. Mikheeva (2005) concludes that the factor of low remuneration is the most strongly influencing the spread of destructive behavior of employees. However, this study shows that many other factors of the organizational environment are approximately equally important determinants of destructive labor behavior. This means that only a complex impact on the organizational system will minimize the destructive motivation of personnel and reduce its manifestations in the form of specific forms of destructive organizational behavior.

The study by E.N. Mikheeva (2005) considers a significant set of various characteristics of the organizational environment that determine the destructive behavior of employees. However, its significant drawback is that when identifying the causes of destructive behavior, various specific forms of this phenomenon are not distinguished. The current study managed to overcome this drawback. The questionnaire identified forms of destructive organizational behavior, which are the most dangerous for the organization, namely: absenteeism (absence of an employee at the workplace without good reason, dawdle, deliberate increase in lunch and other breaks in work, etc.); spreading rumors and deliberate slander; abuse of official authority; violation of organizational regulations; protectionism, patronage by the leader only to "own people": personally loyal subordinates, relatives, friends, acquaintances, etc., in return for their unquestioning support in violation of the norms of the organization and the rights of other employees; fraud; theft; sabotage; malicious destruction of equipment, wasteful use of funds, raw materials, etc.

In the author's opinion, it is necessary to distinguish not only the essential determinants of the destructive behavior of employees, but also to separate them depending on the type of behavior that they determine, considering their danger to the organization. This idea is implemented in the author's empirical study. The empirical study by V.N. Kharitonova (2013) researches one of the forms of manifestation of destructive motivation - clientelism in state institutions. In accordance with the specifics of its goals, it identifies somewhat different factors that determine the spread of clientelism than in the study by E.N. Mikheeva (2005).

The study of the determinants of the spread of clientelism by V.N. Kharitonova (2013) shows that the main ones are the conflict of interests, as well as the personal qualities of the manager.

According to the results of the author's research, the most significant factors determining the destructive behavior of personnel at the organization level are: injustice of remuneration (i.e., the absence of direct correlation between the contribution of the employee to the company's results and the remuneration received) - 87.5\%; the second place goes to too low remuneration $-77.5 \%$ of respondents: the third reason for the destructive motivation is the weakness or lack of control of the employees by the management - $64.1 \%$.

As part of the discussion, the authors presented practical recommendations on limiting the destructive motivation of personnel at the level of the internal environment of the organization: improvement of labor organization; control over the activities of employees; remuneration, benefits and career management; group communications and organizational culture; personal qualities of employees. 


\section{Conclusion}

Summarizing the results of an empirical study of the causes of destructive motivation of personnel in Russian commercial organizations, we came to the following conclusions.

First, the study on the main causes of destructive personnel motivation is based on the results of research on this problem by Russian and foreign scientists, as well as an empirical study conducted by the authors in 2017 in Moscow. Based on the results of these studies, the causes of the destructive behavior of personnel in a number of commercial organizations were established.

Second, the influence of intra-organizational factors on the destructive motivation of personnel was found out in the course of the conducted research.

Third, an essential novelty of this work is to investigate the degree of influence of the characteristics of the internal environment of the organization on the existence of destructive motivation of personnel. The study showed that injustice of remuneration, too low remuneration of labor, weakness or lack of control by management of employees is the main reasons for destructive personnel motivation.

Fourth, the main forms of destructive behavior of personnel were identified in the course of the research and the degree of their danger for commercial organizations was determined as well.

Fifth, the research resulted in confirmation of the hypothesis that the formation of destructive motivation of personnel in commercial organizations is a consequence of interaction of external, intra-organizational and personal factors, the leading role among which is played by organizational reasons. In modern Russian companies, the most important among them are the system of labor remuneration that is unfair from the point of view of employees and an inefficient control system.

Further study of the destructive motivation of personnel, the development of appropriate measures to limit it and their implementation would greatly enhance the efficiency of commercial organizations and would have a significant impact on the positive development of our country as a whole.

\section{References}

Andreeva, T., Yurtaikin, E. 2002. Why do apple fall or internal demotivation of personnel. Top Manager, 22: 46-52. URL: https://www.cfin.ru/management/people/demotivation.shtml [in Russian].

Belkin, V.N., Belkina, N.A. 2009. Demotivation of labor and opportunism of the employees of the organization. Chelyabinsk Humanitarian Scientific Journal, 1(7): 37-46. In print.

Bogdanova, N.Yu. 2010. Opportunistic behavior in commercial companies of Ukraine and Russia: the experience of sociological research. Dissertation of the Candidate of Sciences (Sociology). URL: https://cyberleninka.ru/article/n/opportunisticheskoe-povedenie-kformulirovke-ponyatiya [in Russian].

Boykov, V.E. 2004. Values and goals of social consciousness of Russians. Sociological research, 7: 46-52. URL: http://ecsocman.hse.ru/data/852/838/1219/006.BOIKOV.pdf [in Russian].

Brazevich, D.S., Misyukevich, A.N. 2016. Social conflicts in modern organization and psychological models of their solution. Conflictology, 3: 131-139. URL: https://elibrary.ru/item.asp?id=27327795 [in Russian].

Dankova, E.V. 2017. Professional motivation in the context of deformation of social values. State Service, 3(107): 12-16. URL: https://elibrary.ru/item.asp?id=29869400 [in Russian]. 
The International Journal

ENTREPRENEURSHIP AND SUSTAINABILITY ISSUES

ISSN 2345-0282 (online) http://jssidoi.org/jesi/

2018 Volume 6 Number 1 (September)

http://doi.org/10.9770/jesi.2018.6.(16)

Donskikh, T.A. 1990. Seven ways to a disaster. Destructive behavior in the modern world. Novosibirsk: Nauka. URL: https://books.google.com.ua/books/about/\%D0\%A1\%D0\%B5\%D0\%BC\%D1\%8C_\%D0\%BF\%D1\%83\%D1\%82\%D0\%B5\%D0\%B9_\%D 0\%BA_\%0\%BA\%D0\%B0\%D1\%82\%D0\%B0\%D1\%81\%D1\%82\%D1\%80\%D0\%BE.html?id=m24vAAAAIAAJ\&redir_esc=y [in Russian].

Dudueva, F.A., Lipatova, A.E., Pashko, A.I., Semikhova, M.A., Tretiakov, Ya.A. 2016. Modern researches of personnel. Sociological analysis of managing personnel and employment in dissertational researches. Bulletin of the Moscow University. Series 18. Sociology and politology, 4: 194-216. DOI: https://doi.org/10.24290/1029-3736-2016-22-4-194-216.

Zlokazov, K.V. 2014. Peculiarities of legal regulations of police officers in connection with the destructiveness of personality. Scientific portal of the Ministry of Internal Affairs of the Russian Federation, 3(27): 118-124. URL: https://cyberleninka.ru/article/n/osobennostiformirovaniya-obraza-sotrudnika-politsii-sotsialno-psihologicheskaya-model-i-indikatory-otsenki [in Russian].

Zmanovskaya, E.V. 2004. Deviantology. Psychology of deviant behavior. Moscow: Akademiya. URL: https://www.ereading.club/book.php?book=107411 [in Russian].

Ivanova, S.V. 2013. Motivation for 100\%: Where is its button? Moscow: Alpina Publisher. URL: https://mybook.ru/author/s-vivanova/motivaciya-na-100-a-gde-zhe-u-nego-knopka/read/ [in Russian].

Kudryavtsev, V.N. 2007. Motives struggle in criminal behavior: scientific publication. Moscow: NORMA. URL: https://www.twirpx.com/file/587612/ [in Russian].

Kuznetsova, E.A. 2012. Demotivation of personnel: causes, factors, methods of elimination. Modern research of social problems, 11(19). URL: https://cyberleninka.ru/article/n/demotivatsiya-personala-prichiny-faktory-metody-ustraneniya [in Russian].

Levada-Tsentr. 2013. A quarter of Russians consider it normal to steal at the workplace. Retrieved from: http://rusplt.ru/news/levadatsentrchetvert-rossiyan-schitayut-normalnyimvorovat-na-rabochem-meste.html

Luneev, V.V. 2005. Crime of the XX century: world, regional and Russian trends. Moscow: Walter Kluwer. URL: https://www.twirpx.com/file/950764/ [in Russian].

Mikheeva, E.N. 2005. Destructive labor behavior at regional enterprises in new economic environment: on the example of Volgograd and Volgograd region. Dissertation of the Candidate of Sciences (Sociology). URL: https://cyberleninka.ru/article/n/formy-destruktivnogotrudovogo-povedeniya-rabotnikov [in Russian].

Osintseva, A.V. 2013. Subject-situational approach to the study of the destructive motivation of the officers of Department of Internal Affairs. Scientific bases of professional development of employees of law enforcement bodies. Conference proceedings. Tyumen: Tyumen Institute for Continuing Education of the Officers of Russian Federation Ministry of the Interior, 139-141. In print.

Pink, D. 2013. Drive: What does really motivate us? Moscow: Alpina Publisher. URL: http://moodle.usm.md/moodle/mod/resource/view.php?id=14636 [in Russian]

Popova, A.S. 2014. Research of the structure of professional motivation of teachers in school. Bulletin of medical Internet conferences, 4(11): 1154-1155.

Pugachev, V.P. 2014. Destructive motivation: micro-politics. Deputy Chief Doctor, 2(93): 88-96. URL: https://medconfer.com/node/4253 [in Russian].

Rakitskaya, A.V. 2015. Features of the emotional burnout syndrome in teachers with different levels of personal and situational aggression. Psychology of learning, $\quad 4:$ URL: https://lib.vsu.by/xmlui/bitstream/handle/123456789/3837/\%D0\%A0\%D0\%B0\%D0\%BA\%D0\%B8\%D1\%86\%D0\%BA\%D0\%B0\%D1\%8 F\%20\%D0\%90.\%D0\%92..pdf?sequence=1\&isAllowed=y [in Russian].

Rybyanets, O.V. 2016. The generation theory. Difference in values as determinants of destructive motivation. Actual problems of sociology and management. Interuniversity collection of scientific manuscripts, 19-26. In print.

Simonenko, N.N., Simonenko, V.N. 2011. Transformation of modern models of labor potential motivation. Power and management in the East of Russia, 4: 73-81. In print. 
The International Journal
ENTREPRENEURSHIP AND SUSTAINABILITY ISSUES

ISSN 2345-0282 (online) http://jssidoi.org/jesi/ 2018 Volume 6 Number 1 (September) http://doi.org/10.9770/jesi.2018.6.(16)

Snisarenko, I.M. 2017. Social determinants of the self-development of the company's personnel. Theory and practice of social development, 5: 60-65. URL: https://cyberleninka.ru/article/n/sotsialnye-determinanty-samorazvitiya-personala-organizatsii-1 [in Russian].

Spivak, V.A. 2006. The concept of developing personnel management. Personnel development management, 3: 52-61. URL: https://www.litres.ru/vladimir-spivak/upravlenie-personalom-uchebnoe-posobie/chitat-onlayn/page-3/ [in Russian].

Tkachenko, N.E. 2011. Risk of personnel demotivation: analysis of structural characteristics and possibilities of transformation. Economics. Management. Entrepreneurship, 23(II): 90-99. URL: http://www.vuzlib.com.ua/articles/book/35055Risk_demotiva\%D1\%81ii_personala_an/1.html [in Russian].

Fedosova, I.V. 2016. Professional deformation of the personality of a teacher: diagnostics and prevention. Azimuth of scientific researches: pedagogy and psychology, 3(16): 191-195. URL: https://elibrary.ru/item.asp?id=27018703 [in Russian].

Florovskiy, S.Yu. 2011. Micro-political aspects of managerial interaction of the leaders of the organization. Proceedings of the All-Russian Scientific and Practical Conference Actual problems of theoretical and applied psychology: traditions and perspectives. Yaroslavl, May 19-21, 2011, 3. In print.

Khalliullina, R. 2010. Destructive criticism - the destroyer of employee's motivation. Human resource management, 19: 48-51. URL: http://www.top-personal.ru/issue.html?2567 [in Russian].

Kharitonova, V.N. 2013. Clientelism in the civil service: causes and ways for limitation. Dissertation of the Candidate of Sciences (Sociology). URL: http://emsu.ru/face/dissert/avtoreferat_haritonovavn.pdf [in Russian].

Sprenger, R. 2007. Rebellion of the individual. The reasons why we should completely rethink the essence of management? Kaluga: Spiritual knowledge. URL: https://www.labirint.ru/books/158901/ [in Russian].

Auriol, E., Brilon, S. 2018. Nonprofits in the field: an economic analysis of peer monitoring and sabotage. Annals of Public and Cooperative Economics, 89(1): 157-174. https://doi.org/10.1111/apce.12197

Bashir, S., Nasir, M., Qayym, S., Bashir, A. 2012. Dimensionality of counterproductive work behaviors in public sector organizations of Pakistan. Public Organization Review, 12: 357-366. https://doi.org/10.1007/s11115-012-0177-8

Blickle, G., Solga, M: 2006. Einfluss. Konflikte, Mikropolitik. Lehrbuch der Personalpsychologie, 2: 611-650. URL: https://books.google.com.ua/books/about/Lehrbuch der Personalpsychologie.html?id=2cNIQJ3AV0wC\&redir esc=y

Brown, R.M., Brown, S.L., Johnson, A., Olsen, B., Melver, K., Sullivan, M. 2009. Empirical Support for an Evolutionary Model of SelfDestructive Motivation. Suicide and Life-Threatening Behavior, 39(1): 1-12. https://doi.org/10.1521/suli.2009.39.1.1

Dhar, R.L. 2012. Why do they bully? Bulling behavior and its implication on the bullied. Journal of Workplace Behavioral Health, 27(2): 79-99. https://doi.org/10.1080/15555240.2012.666463

Dudina, V.I. 2017. Strategies of metatheorizing in sociology. Sotsiologicheskie Issledovaniya, 12: 10-19. https://doi.org/10.7868/S0132162517120029

Faullant, R., Dolfus, G. 2017. Everything community? Destructive processes in communities of crowdsourcing competitions. Business Process Management Journal, 23(6): 1108-1128. https://doi.org/10.1108/BPMJ-10-2016-0206

Hommelhaft, S. 2017. Implicit managerial theories about followers and customers. Journal of Service Theory and Practice, 27(1): 47-68. https://doi.org/10.1108/JSTP-05-2015-0124

Indradevi, R. 2016. Toxic leadership over the years - A review. Purushartha, 9(1): 106-110. URL: https://www.researchgate.net/publication/317936124_Toxic_leadership_over_the_years___A_review

Ivanov, D.V. 2016. New configuration of inequality and flow structures of glam-capitalism. Sotsiologicheskie Issledovaniya, 6: 13-23. URL: http://socis.isras.ru/en/article/6220 
The International Journal

ENTREPRENEURSHIP AND SUSTAINABILITY ISSUES

ISSN 2345-0282 (online) http://jssidoi.org/jesi/

2018 Volume 6 Number 1 (September)

http://doi.org/10.9770/jesi.2018.6.(16)

Ma, C. 2016. The role of approach and avoidance motivation in employee voice: The moderating effect of ostracism and contingent selfesteem. International Journal of Productivity and Performance Management, 65(6): 744-759. https://doi.org/10.1108/IJPPM-01-2016$\underline{0002}$

Neuberger, 2015. O. Mikropolitik und Moral in Organisationen. Herausforderung der Ordnung 2. Stuttgart: Lucius \& Lucius. URL: https://books.google.com/books/about/Mikropolitik_und_Moral_in_Organisationen.html?id=q4eyygAACAAJ

Schütz, M. 2015. Die Macht der Mitarbeiter. Was Mikropolitik in Unternehmen bewirkt. Frankfurter Rundschau. URL: http://www.fr.de/wirtschaft/gastwirtschaft/gastwirtschaft-die-macht-der-mitarbeiter-a-445739 [in German].

Rothlin, P., Werder, P.R. 2008. Bore out!: overcoming workplace demotivation. London: Kogan Page Limited. ISBN: 978-0749453398.

Rubtcova, M.V., Mart'yanova, M.V. 2015. Professionalism. Cambridge: Polity Press. In print.

Rubtcova, M., Vasilieva, E. 2015. Managing Human Capital: How Public Servants Support the Governance's Performance Conception in Russia. Proceedings of 2015 International Conference on Public Administration (11th), 1: 237-247. URL: https://papers.ssrn.com/sol3/papers.cfm?abstract_id=2679549

Sackett, P.; Berry, C.; Wiemann, S.; Laczo, R. 2006. Citizenship and Counterproductive Behavior: Clarifying Relations Between the two Domains. Human Performance, 19(4): P. 441-464. https://doi.org/10.1207/s15327043hup1904_7

Skvortsov, N.G. 1999. Ethnicity: a sociological perspective. Sotsiologicheskie Issledovaniya, 1: 21-31. In print.

Spector, P.E., Fox, S., Domagalski, T. 2006. Emotions, Violence and Counterproductive Work: Behavior. Thousand Oaks, CA: Sage. URL: http://scholarcommons.usf.edu/psy_facpub/584/

Vasilieva, E., Rubtcova, M. 2017. Content analysis of representation of public administration in mass media: evidence from Russia? $\begin{array}{lllll}\text { Persrectivas de la } & \text { communicacion, } & 10(1): & 109-118 .\end{array}$ https://www.researchgate.net/publication/281481754_Representations_of_Trust_to_Public_Service_in_Russian_Newspapers_during_Elect ion_Time_Corpus-based_Content_Analysis_in_Public_Administration_Sociology

Veselov, Y.V. 2000. Economic development of Russia. Reforms and the Russian national economy. Sotsiologicheskie Issledovaniya, 5: 146-149. In print.

Vogel, R., Homberg, F., Gericke, A. 2016. Abusive supervision public service motivation and employee deviance: The moderating role of employment sector. Evidence-based HRM, 4(3): 214-231. https://doi.org/10.1108/EBHRM-08-2015-0034

Vogel, R.M., Mitchell, M.S. 2017. The motivational Effects of Diminished Self-Esteem for Employees Who Experience Abusive Supervision. Journal of Management, 43(7): 2218-2251. URL: http://journals.sagepub.com/doi/abs/10.1177/0149206314566462 


\section{ENTREPRENEURSHIP AND SUSTAINABILITY ISSUES \\ The International Journal}

ISSN 2345-0282 (online) http://jssidoi.org/jesi/ 2018 Volume 6 Number 1 (September) http://doi.org/10.9770/jesi.2018.6.(16)

Alexandr BORISOV is the Doctor of Sciences (Sociology), the Professor of the Social Management and Planning Department at SaintPetersburg State University.ORCID ID: 0000-0001-9533-5038

Diana NAROZHNAIA is the Candidate of Sciences (Sociology), the Assistant at the Personnel Management School of the State Management Department at the Moscow State University n.a. M.V. Lomonosov.ORCID ID: 0000-0001-7690-3546

Elena TARANDO is the Doctor of Sciences (Economics), the Professor of the Economic Sociology School at Saint-Petersburg State University. ORCID ID: 0000-0002-2474-2602

Alekcey VORONTSOV is the Doctor of Sciences (Philosophy), Professor at the Herzen State Pedagogical University of Russia. ORCID ID: 0000- 0002-0194-7293

Nikolay PRUEL is the Professor of the Social Management and Planning Department at Saint-Petersburg State University. ORCID ID: 0000-0002-9005-0102

Olga NIKIFOROVA is the Candidate of Sciences (Sociology), Associate Professor of the Economic Sociology School at Saint-Petersburg State University. ORCID ID: 0000-0002-5128-5195

Copyright (C) 2018 by author(s) and VsI Entrepreneurship and Sustainability Center

This work is licensed under the Creative Commons Attribution International License (CC BY).

http://creativecommons.org/licenses/by/4.0/

(c) (i) Open Access 